\title{
Anti-Oxidant and Enzyme-Inhibitory Potential of Marine Streptomyces
}

\author{
Revathy, T., M.A. Jayasri and K. Suthindhiran \\ Division of Environmental Biotechnology, \\ School of BioSciences and Technology, VIT University, Vellore-632 014, Tamil Nadu, India
}

Received 2012-05-24, Revised 2013-07-03; Accepted 2013-07-23

\begin{abstract}
Marine actinomycetes are potential source for the discovery of novel compounds and enzymes. Though extensive research on marine actinomycetes is underway globally, the actinomycetes research from Indian marine ecosystem is unexplored and understudied. Hence, the present research is focussed on the screening of bioactive compounds from marine actinomycetes isolated from Indian coastal region. This study is designed to determine the antioxidant and enzyme inhibitory potential of Streptomyces sp. VITMSS05 strain, isolated from Marakkanam, southern coast of India. An actinomycetes strain designated as VITMSS05 was isolated. This strain was cultivated in Starch Caesin Agar medium (SCA) supplemented with sea water. The cultural, morphological and molecular characterization was determined for the isolate. The crude extract of the isolate was extracted with ethyl acetate. Antioxidant activity of the crude extract was determined by DPPH radical scavenging assay. Alpha amylase and alpha glucosidase inhibitory potential of the extract was determined. Based on the phenotypic and phylogenetic analysis the strain was identified as Streptomyces sp. Significant antioxidant activity of the extract was observed with an IC50 value of $92.49 \mu \mathrm{g} \mathrm{mL}^{-1}$. The extract shows $64.1 \%$ inhibition on $\alpha$-amylase and $91.5 \%$ inhibition on $\alpha$-glucosidase at $100 \mu \mathrm{g} \mathrm{mL}^{-1}$ with an IC50 value of 385.97 and $42.89 \mu \mathrm{g} \mathrm{mL}^{-1}$. From the results it is evident that the ethyl acetate extract of Streptomyces sp. VITMSS05 has potent antioxidant and enzyme inhibitory activity in vitro. The combined effect of free radical scavenging and enzyme inhibition makes it a potent anti diabetic drug.
\end{abstract}

Keywords: Anti Oxidant, $\alpha$-Amylase, $\alpha$-Glucosidase, Streptomyces sp. VITMSS05

\section{INTRODUCTION}

It has been estimated that 285 million people, worldwide, have diabetes and there will be a $54 \%$ increase by 2030 (Shaw et al., 2010). Various pharmacological approaches have been used to treat diabetes; one of the most beneficial therapies is to reduce the post prandial glycemia after the meal (Kim et al., 2005). The absorption of glucose can be retarded by inhibiting the carbohydrate hydrolysing enzymes (Kim et al., 2005) thereby resulting in decrease in postprandial hyperglycemia. The breakdown of starch to maltose and maltose to glucose was carried out by $\alpha$ Amylase and the released glucose will be utilized by the body (Kotowaroo et al., 2006). $\alpha$-glucosidase catalyzes the final step in the digestive process of carbohydrates. Its inhibitors can retard the uptake of dietary carbohydrates and suppress postprandial hyperglycemia and could be useful for treating diabetic and obese patients (Toeller, 1994). Enzyme inhibitors are now receiving increased attention, not only for studying the enzyme structure and reaction mechanism but also for

Corresponding Author: Revathy, T., Division of Environmental Biotechnology, School of BioSciences and Technology, VIT University, Vellore-632 014, Tamil Nadu, India 
pharmacological (Bode and Huber, 1992) and agricultural applications (Terashita et al., 1980). Alpha amylase and alpha glucosidase inhibitors such as acarbose, valiolamine, trestatin and amylostatin were isolated from microorganisms (Remi and Jean, 2004) and have been used to control the diabetes. Streptomyces is a proven source of microbial enzyme inhibitors (Umezawa, 1972).

Apart from enzyme inhibitors free radicals also responsible for type II diabetes. Free radicals are the product of normal metabolism but oxygen metabolites are toxic (Halliwell and Gutteridge, 1989; Yu, 1994) and activate nuclear factor $-\kappa \mathrm{B}$ resulting in upregulation of interleukin-1, interleukin-8 and tumor necrosis factor (Grimble, 1994). They cause oxidative damage to biomolecules such as proteins, lipids, lipoproteins and DNA (Shetgiri and Mello, 2003; Gopinathan et al., 2004). Several enzymes and radical scavengers (Nasik, 2003) possessed by our body which constitute the repair systems for biomolecules are damaged by free radicals (Gopinathan et al., 2004). Antioxidants can either inhibit or delay the oxidation of the substrate in a chain reaction and therefore appear to be important (Halliwell et al., 1992). Previous research reports suggest that actinomycetes are potential producers of antioxidant compounds (Isik et al., 2006).

Marine Actinomycetes have emerged as a rich source of novel compounds. Actinomycetes are potent source for the production of antibiotics and other secondary metabolites. Each strain has the potential to produce 10-20 metabolites (Bently et al., 2002; Sosio et al., 2000). The marine environment exhibits different characteristics when compared to the terrestrial environment and they have a potential for new enzymeinhibitors and antioxidants. Reports states that actinomycetes are powerful producers of antioxidants and enzyme inhibitors (Bull et al., 2000). The objective of this study is to investigate the antioxidant and enzyme inhibitory activity of marine Streptomyces isolated from marakkanam salt pan.

\section{MATERIALS AND METHODS}

\subsection{Sampling and Isolation}

The soil samples were collected from the depth of 2 feet from Marakkanam (Latitude (N) 1315, Longitude (E) $80^{\circ} 21^{\prime}$ ) coast, India. The samples were transported to the laboratory aseptically. The samples were dried in room temperature and used for isolation. Serial dilution of the sample was done and aliquots of each dilution were plated on to starch casein agar plates. The media was prepared with $25 \%$ sea water and $25 \%$ soil extract (Prepared by mixing the air dried soil sample and water and then filtered) and the growth media was supplemented with antibiotics such as AmphotericinB $\left(25 \mu \mathrm{g} \mathrm{mL} \mathrm{m}^{-1}\right)$ and streptomycin sulphate $(25 \mu \mathrm{g}$ $\mathrm{mL}^{-1}$ ) (Himedia, Mumbai, India). The plates were incubated at room temperature for 7-15 days. The strains were subcultured regularly inorder to keep them viable for longer period.

\subsection{Media and Cultural Condition Optimization}

The cultural conditions were determined by inoculating the isolate in various media (SCA, ISP1, ISP2, ISP3 and AIA) and the growth was investigated. The effects of cultural conditions like different incubation temperatures $\left(15,30,37\right.$ and $\left.45^{\circ} \mathrm{C}\right)$, different $\mathrm{pH}(3,5,6,7$ and 9) and $\mathrm{NaCl}$ concentrations $(1,3,5,7$ and 9) on the growth of the isolate were studied by measuring the dry mycelial weight.

\subsection{Taxonomy}

The morphological, cultural, physiological and biochemical characterization of the isolates were carried out as described in International Streptomyces Project (ISP). The morphology was observed at light microscope and the substrate mycelium was further analyzed by scanning electron microscopy (Hitachi S4000). The Hipura bacterial DNA isolation and purification kit (Himedia, India) was used for the isolation of DNA and amplified by PCR using a master kit and Medoxmix (Medox, India). Universal 16S rRNA primers were used (forward primer FC27 and reverse primer RC 1492) for the amplification of $16 \mathrm{~S}$ rDNA. Using the earlier reports (Mincer et al., 2002; Magarvey et al., 2004) the methodology for sequencing was adapted. An NCBI BLAST search was performed and a phylogenetic tree was generated using the neighbour joining method (Saito and Nei, 1987). MEGA version 4 software was used to display the phylogenetic tree.

\subsection{Metabolite Extraction}

The strain was inoculated into SCA broth supplemented with a $\mathrm{pH}$ of 7.2 and incubated for 7 days in a rotary shaker $(110 \mathrm{rpm})$ at $28^{\circ} \mathrm{C}$. The growth was checked every day. After seven days of incubation the broth was collected and centrifuged at $10000 \mathrm{rpm}$ for 10 $\min$ at $10^{\circ} \mathrm{C}$. The supernatant was separated from the pellet. The supernatant was extracted twice with ethyl acetate and the extract was concentrated in rotary vaccum and the lyophilized extract was used to carry out the assays. $\alpha$-Amylase inhibition assay: The $\alpha$-amylase inhibitory assay was carried out as described earlier 
(Suthindhiran et al., 2009). $\alpha$-Amylase solution (0.5 mg $\mathrm{mL}^{-1}$ ) was prepared in $0.02 \mathrm{M}$ Sodium phosphate buffer. The crude extracts with different concentration were taken. About $500 \mu \mathrm{l}$ of the extract was added to $500 \mu \mathrm{L}$ of the enzyme solution and incubated for $10 \mathrm{~min}$ at $25^{\circ} \mathrm{C} .1 \%$ starch solution prepared in 0.02 $\mathrm{M}$ Sodium phosphate buffer was added to each tube and incubated at $25^{\circ} \mathrm{C}$ for $10 \mathrm{~min}$. About $1 \mathrm{~mL}$ of dinitrosalicylic acid was added to stop the reaction. The test tubes were incubated in boiling water bath for $5 \mathrm{~min}$ and then cooled to room temperature. The reaction mixture was then diluted by adding $10 \mathrm{~mL}$ of distilled water and the absorbance was measured at 540 $\mathrm{nm}$. The percentage of inhibition was calculated by:

$$
\begin{gathered}
\% \text { inhibition }=[(\text { A540 control-A540 extract })] \\
\text { X 100/A540 control }
\end{gathered}
$$

$\alpha$-Glucosidasde inhibition assay: The $\alpha$-glucosidase inhibitory assay was carried out as described earlier (Suthindhiran et al., 2009). About $50 \mu \mathrm{L}$ of extract (different concentrations) was added to $100 \mu \mathrm{L}$ of $\alpha$ glucosidase solution $(1.0 \mathrm{U} / \mathrm{mL})$ prepared with $0.1 \mathrm{M}$ phosphate buffer (pH-6.9) were incubated in 96 well plates at $25^{\circ} \mathrm{C}$ for $10 \mathrm{~min}$. Then $50 \mu \mathrm{L}$ of $5 \mathrm{Mm} \mathrm{p}$ nitrophenyl $\alpha$-D-glucopyranoside solution in $0.1 \mathrm{M}$ phosphate (pH- 6.9) was added to each well. After incubation the absorbance at $405 \mathrm{~nm}$ was read at micro array reader and compared to the control which had 50 $\mu \mathrm{L}$ of buffer solution in place of the extract. The percentage of inhibition was calculated by:

$$
\begin{gathered}
\% \text { inhibition }=[(\text { control405-extract } 405)] \\
\text { X 100/control540 }
\end{gathered}
$$

\subsection{Antioxidant Activity}

The antioxidant activity was carried out as described earlier (Yang et al., 2006). The concentrations of extracts and DPPH were $1 \mathrm{mg} \mathrm{mL}^{-1}$ and $0.002 \%$ respectively. $2 \mathrm{~mL}$ of DPPH solution was mixed with $2 \mathrm{~mL}$ of extract. The reaction mixture was incubated in dark for $30 \mathrm{~min}$. The optical density was measured at $517 \mathrm{~nm}$ using UV-Vis Spectrophotometer. The scavenging activity of the extract against the stable DPPH was calculated using the following equation:

$$
\text { Scavenging activity }(\%)=\mathrm{A}-\mathrm{B} / \mathrm{A} \times 100
$$

where, $\mathrm{A}$ is the absorbance of DPPH solution and B was the absorbance of DPPH solution with extract.

\subsection{Statistical Analysis}

All analysis were carried out in triplicate and the data were expressed as mean $\pm \mathrm{SE}$ (standard error).

\section{RESULTS}

The cultural, morphological, biochemical and physiological characteristics reveals that the strain VITMSS05 belongs to the genus Streptomyces. The isolated organism is gram positive and non-motile. The aerial mycelium is branched with long spore chains (Fig. 1). The colonies were white to grey in colour instarch casein agar medium. The spore surface is smooth when observed at $10 \mu \mathrm{m}$ under scanning electron microscope. Diffusible pigment and melanin pigment were not been produced by the strain. The strain shows abundant growth in Starch casein agar medium and the strain grows well when cultivated at $28^{\circ} \mathrm{C}$ at $\mathrm{pH} 7.4$.

The strain requires $3 \% \mathrm{NaCl}$ for optimal growth. Among carbon sources the strain shows abundant growth in fructose, galactose and lactose but failed to grow in maltose, mannitol and xylulose. The effect of $\mathrm{pH}$, Temperature and salt concentration on the growth of the isolate is given in the Table 1. The strain shows good growth in $\mathrm{pH} 6,7$ and 9, while it shows moderate growth in $\mathrm{pH}$ 5. The strain grows at temperatures $28,37^{\circ} \mathrm{C}$ and the optimum temperature was found to be $28^{\circ} \mathrm{C}$.

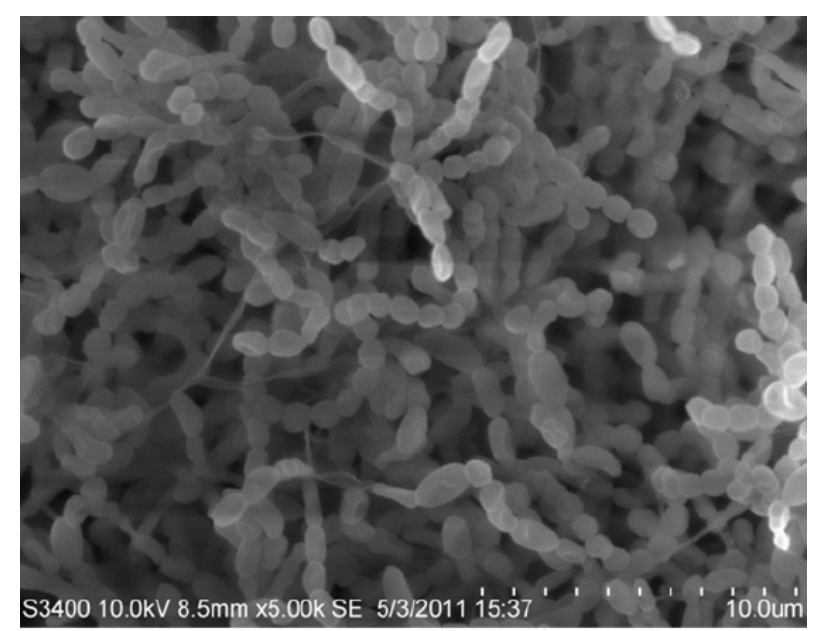

Fig. 1. Scanning electron micrograph of VITMSS05 grown in optimized medium at $28 \mathrm{oC}$ for 5 days. (The bar represents $5 \mu \mathrm{m}$ ) 
T. Revathy et al. / American Journal of Biochemistry and Biotechnology 9 (3): 282-290, 2013

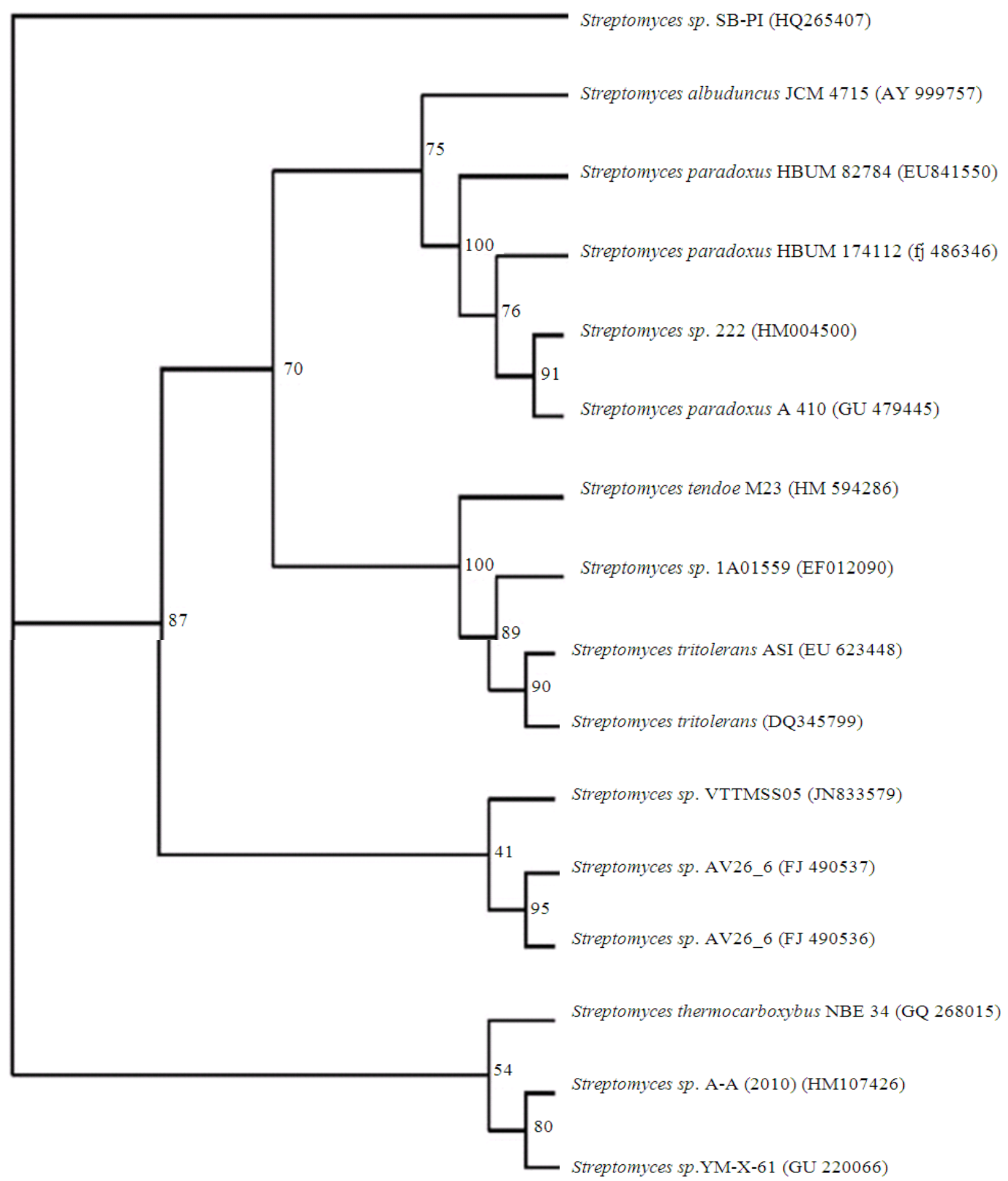

Fig. 2. The phylogram showing the position of strain VITMSS05 with other Streptomyces based on 16S rRNA partial gene sequence 
T. Revathy et al. / American Journal of Biochemistry and Biotechnology 9 (3): 282-290, 2013

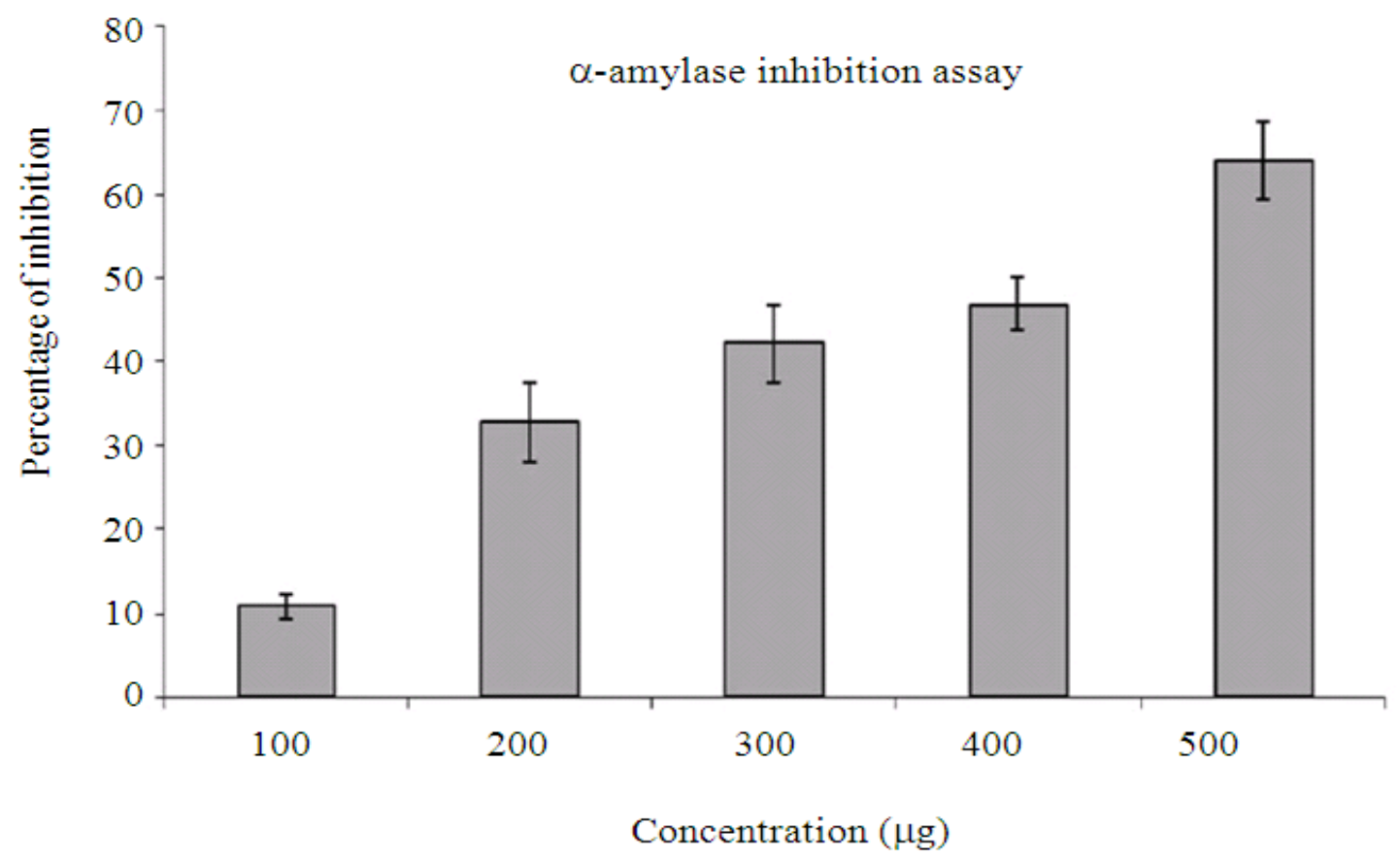

Fig. 3. DPPH (1, 1- diphenyl 2-picryl hydrazyl) scavenging activity of compound extracted from Sterptomyces sp. VITMSS05. The values are mean \pm SD

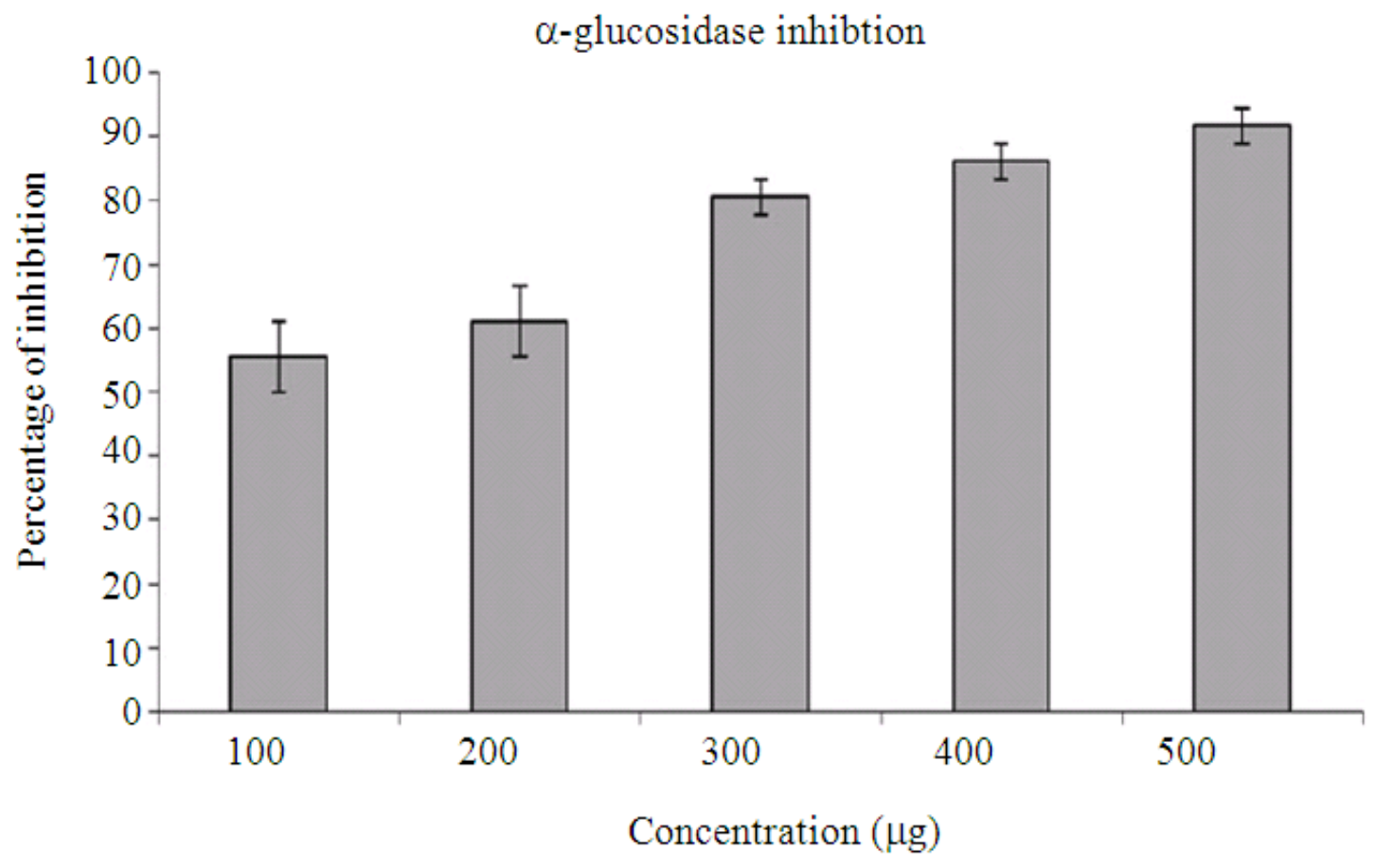

Fig. 4. $\alpha$-Amylase inhibitory potential of Sterptomyces $s p$. VITMSS05. The values are mean \pm SD 


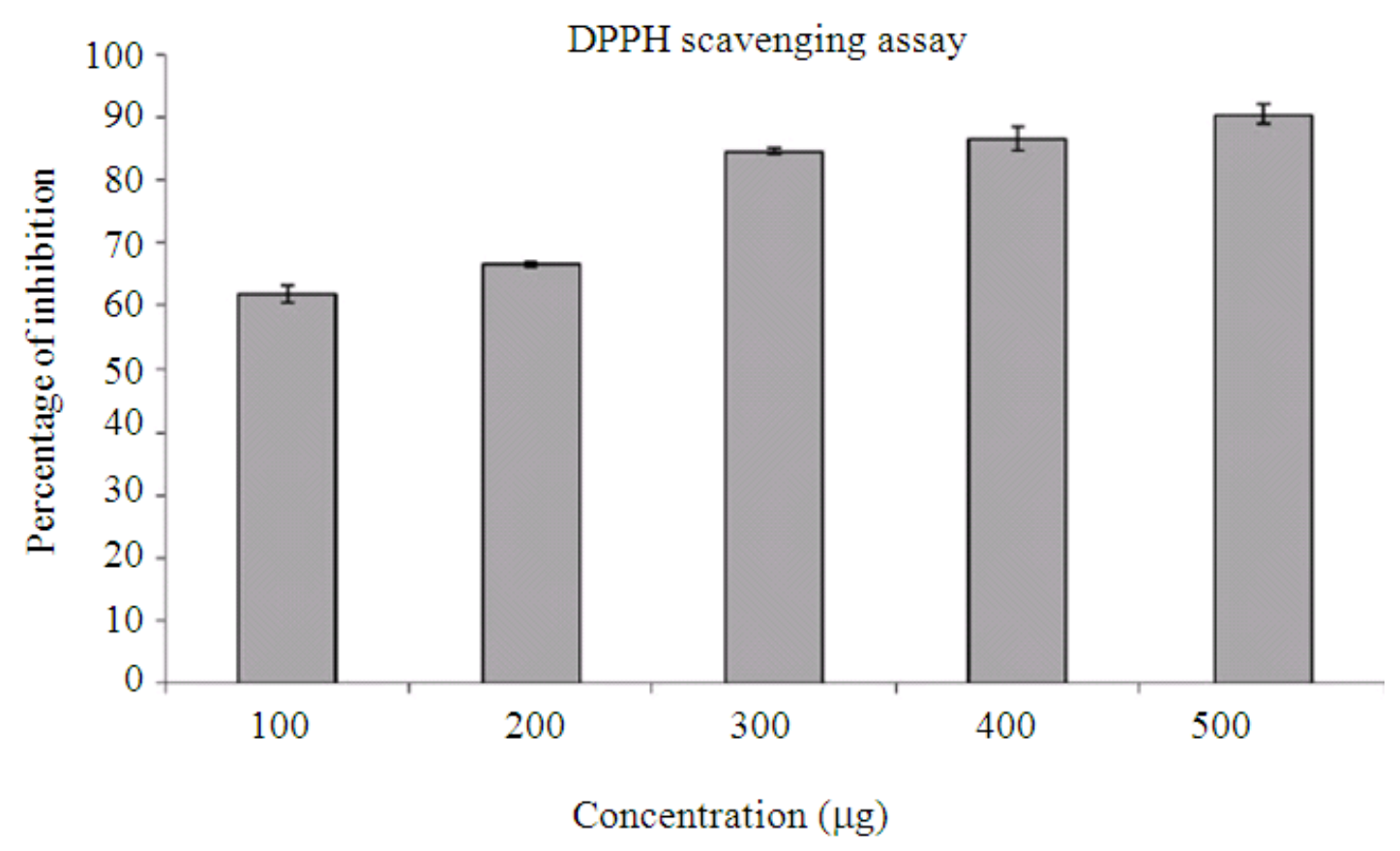

Fig. 5. $\alpha$-Glucosidase inhibitory activity of Streptomyces $s p$. VITMSS05. The values are mean \pm SD

\subsection{Molecular Taxonomy}

NCBI BLAST search analysis showed that the sequence was $99 \%$ similar with that of Streptomyces tritolerans. A neighbour joining tree based on 16S rDNA sequences showed that the isolate occupies a distinct phylogenetic position within the radiation including representatives of the Streptomyces family. A phylogenetic tree was constructed based on kimura method, also showed distinct position of the isolate (Fig. 2). Based on the molecular taxonomy and phylogeny the strain was identified as Streptomyces and designated as Streptomyces sp. VITMSS05. The 16S rRNA sequences were submitted to the GenBank under the accession number JN833579.

\subsection{Alpha Amylase and Alpha Glucosidase Inhibition}

The In vitro Alpha amylase inhibitory activity demonstrates that the ethyl acetate extract of the strain VITMSS05 has inhibitory activity. Significant inhibition exhibited by the ethyl acetate extract at a concentration of $500 \mu \mathrm{g} \mathrm{mL}^{-1}$ with $61.1 \%$ inhibition. The $\mathrm{IC}_{50}$ value for alpha amylase inhibition is $385.97 \mu \mathrm{g} \mathrm{mL}^{-1}$. Activity increases with increase in the concentration (Fig. 3). The In vitro alpha glucosidase activity of the ethyl acetate extract of the strain VITMSS05 is given in the Fig. 3. Analysis of the data confirms that maximum inhibition $(91.5 \%)$ was seen at $500 \mu \mathrm{gL}^{-1}$ (Fig. 4). The IC50 value for alpha glucosidase inhibition is $42.89 \mu \mathrm{g} \mathrm{mL}^{-1}$.

\subsection{Antioxidant Assay}

The results of the DPPH scavenging activity of VITMSS05 extract was shown in the Fig. 5. In this study the ethyl acetate extract of the strain VITMSS05 showed $90.57 \%$ activity at $500 \mu \mathrm{g} \mathrm{mL}^{-1}$ concentration. The IC50 value of the extract is $92.49 \mu \mathrm{g} \mathrm{mL}^{-1}$. The antioxidant activity was found to be dose dependent.

\section{DISCUSSION}

Marine micro organisms are known to produce various novel metabolites. Among microorganisms, Actinomycetes are the largest producer of antibiotics (Lazzarini et al., 2000) and other novel metabolites. These actinobacteria produces resistant spores and are salt tolerant (Okazaki and Okami, 1975). In the present study we have isolated Streptomyces sp. VITMSS05 from Marakkanam salt pan. Comparison of $16 \mathrm{~S}$ rRNA sequences of the strain VITMSS05 with the corresponding sequences confirmed that VITMSSO5 belonged to the genus Streptomyces. 
Table 1. Effect of $\mathrm{pH}$, Temperature and Salt concentration on the growth of VITMSS05

\begin{tabular}{|c|c|}
\hline Different parameters & Results \\
\hline \multicolumn{2}{|l|}{ Effect of Temperature } \\
\hline $15^{\circ} \mathrm{C}$ & No growth \\
\hline $28^{\circ} \mathrm{C}$ & Abundant growth \\
\hline $37^{\circ} \mathrm{C}$ & moderate growth \\
\hline $45^{\circ} \mathrm{C}$ & moderate growth \\
\hline \multicolumn{2}{|l|}{ Effect of $\mathrm{pH}$} \\
\hline 5 & Moderate growth \\
\hline 6 & Good growth \\
\hline 7 & Good growth \\
\hline 9 & Good growth \\
\hline \multicolumn{2}{|l|}{ Effect of $\mathrm{NaCl}$} \\
\hline $1 \%$ & Good growth \\
\hline $3 \%$ & Good growth \\
\hline $5 \%$ & Moderate growth \\
\hline $7 \%$ & No growth \\
\hline \multicolumn{2}{|l|}{ Nitrogen sources } \\
\hline Citrate & Positive \\
\hline Nitrate & Negative \\
\hline Urease & Positive \\
\hline Gelatin & Negative \\
\hline Carbon & sources \\
\hline Maltose & No growth \\
\hline Mannitol & No growth \\
\hline Xylulose & No growth \\
\hline Galactose & Good growth \\
\hline Lactose & Good Growth \\
\hline Fructose & Good growth \\
\hline
\end{tabular}

The strain shows $99 \%$ similarity with Streptomyces tritolerans ASI which has been isolated from earthworm gut and shows activity against plant pathogenic bacteria and fungi. Streptomyces AV26_2 shows 99\% similarity with our strain and was isolated from leaf cutting ants, this strain produces candicidin macrolide and shows antifungal activity. Xylosidase enzyme producing strain Streptomyces sp. YMX-6, shows 99\% similarity with our strain. The substrate mycelium is highly branched and the hyphae differentiated into long chain spores. The strain does not produce any soluble pigments. Morphological and cultural characteristics indicate that the strain VITMSS05 can be assigned to the genus Streptomyces. The strain utilizes galactose, fructose and lactose. The culture was optimized with varying media, salt and carbon sources (Table 1) to enrich the yield of metabolite.

The strain was found to be moderately halophilic as it grows at salt concentrations ranging from 5-20\%. We have already isolated many strains of actinomycetes which were found to have several bioactivities (Suthindhiran and Kannabiran, 2009a; 2009b; Suthindhiran et al., 2011; Suthindhiran and Kannabiran, 2010).

About $90-95 \%$ of patients have type II diabetes and the treatment for type II diabetes has many limitations (Mark and Grell, 1997). $\alpha$-amylase and $\alpha$-glucosidase are the major enzymes involved in type II diabetes. Inhibitors of these enzymes will inhibit the glucose liberation from carbohydrates and delay the absorption of glucose which will result in postprandial hyperglycemia (El-Ashry, 2000; Franco et al., 2002; Jayasri et al., 2009). So metabolites from marine origin can be used to treat II diabetes. Recently, Micromonospora sp. VITSDK3 was reported for its efficient production of $\alpha$-amylase and $\alpha$-glucosidase inhibitors (Suthindhiran et al., 2009). In our study, the extract showed $64.1 \%$ inhibition (Fig. 3) of $\alpha$-Amylase enzyme and $91.5 \%$ inhibition (Fig. 4) of $\alpha$-glucosidase at a concentration of $500 \mu \mathrm{g} \mathrm{mL}^{-1}$. We have focussed on both the aspect of inhibiting the enzymes responsible for diabetes and also the free radical scavenging ability. Free radicals are highly unstable which cause damage to other molecules and attain stability by extracting electrons from them (Ali et al., 2009). Natural antioxidants are associated with health benefits (Ali et al., 2009). Dietary antioxidants inhibit peroxidation chain reactions and have a protective effect against diabetes development (Feskens et al., 1995). Previous reports states that Streptomyces metabolise the compounds with antioxidant activity such as isoflavonoids (Komiyama et al., 1989), diphenazithionin (Hosoya et al., 1996), dihydroherbimycin A (Chang and Kim, 2007), polysaccharide (He et al., 2008) and protocatechualdehyde (Kim et al., 2008). The ethyl acetate extract of our isolated strain showed $90.57 \%$ ofradical scavenging activity. The findings of the present study clarify that enzyme inhibitors and antioxidants were present in the compound which can be used to treat diseases. Further, the chemistry and mechanism of these compounds need to be investigated.

\section{CONCLUSION}

In this study the ethyl acetate extract of Streptomyces $s p$. shows significant inhibition against porcine pancreatic amylase and yeast glucosidase and also has the potential to scavenge the free radicals. Further structural and invivo studies of these compounds will be helpful for the development of new drug for the treatment of diabetes. 


\section{ACKNOWLEDGEMENT}

The researchers' wish to thank the management, VIT University for providing all necessary facilities.

\section{REFERENCES}

Ali, B., H. Mohamed, B. Rafik, L. Lmen and T. Yosra et al., 2009. Antioxidant and free radical-scavenging activities of smooth hound (Mustelus mustelus) muscle protein hydrolysates obtained by gastrointestinal proteases. J. Food Chem., 114: 1198-1205. DOI: 10.1016/j.foodchem.2008.10.075

Bently, S.D., A.M. Chater, C. Cerdeno-Tarranga and N.R. Thomson, 2002. Complete genome sequence of the model actinomycete Streptomyces coelicolor A3 (2). Nature, 417: 141-147. DOI: 10.1038/news020506-8

Bode, W. and R. Huber, 1992. Natural protein proteinase inhibitors and their interaction with proteinases. Eur. J. Biochem., 204: 433-451. PMID: 1541261

Bull, A.T., A.C. Ward and M. Goodfellow, 2000. Search and discovery strategies for biotechnology: The paradigm shift. Microbiol. Mol. Biol. Rev., 64: 573606. PMCID: PMC99005

Chang, H.B. and J.H. Kim, 2007. Antioxidant properties of dihydroherbimycin A from a newly isolated Streptomyces sp. Biotechnol. Lett., 29: 599-603. PMID: 17206369

El-Ashry, E.S., 2000. Glycosidase inhibitors and their chemotherapeutic value, part 1. Pharmazie, 55: 251262. PMID: 10798237

Feskens, E.J.M., S.M. Virtanen, L. Räsänen and J. Tuomilehto et al., 1995. Dietary factors determining diabetes and impaired glucose tolerance. A 20-year follow-up of the Finnish and Dutch cohorts of the Seven Countries Study. Diabetes Care., 18: 11041112. PMID: 7587845

Franco, O. L., D. J. Rigden, F. R. Melo, M. F. GrossiDe-Sa, 2002. Plant alpha-amylase inhibitors and their interaction with insect alpha-amylases. Eur. J. Biochem., 269: 397-412. PMID: 11856298

Gopinathan, N., K.K. Srinivasan and J.E. Mathew, 2004. Free radical scavenging properties of ethanol extract of Saccharum spontaneum. Ind. Drugs., 41: 633635.

Grimble, R.F., 1994. Nutritional antioxidants and the modulation of inflammation: Theory and practice. New Horiz., 2: 175-185. PMID: 7922442
Halliwell, B. and J.M. Gutteridge, 1989. Free Radicals in Biology and Medicine. 2nd Edn., Clarendon Press, Oxford, ISBN-10: 0198552912, pp: 543.

Halliwell, B., J.M. Gutteridge, C.E. and C.E. Cross, 1992. Free radicals, antioxidants and human disease: Where are we now? J. Laboratory Clinical Med., 119: 598-620. DOI: 10.1016/S0140-6736(94)92211$\mathrm{X}$

He, F., Y. Yang, G. Yang and L. Yu, 2008. Components and Antioxidant Activity of the Polysaccharide from Streptomyces virginia H03. Zeitschrift Naturforsch. C., 63: 181-188. PMID: 18533459

Hosoya, Y., H. Adachi, H. Nakamura, Y. Nishimura and H. Naganawa et al., 1996. The structure of diphenazithionin, a novel antioxidant from Streptomyces griseus ISP 5236. Tetrahedron Lett., 37: 9227-9228. DOI: 10.1016/S0040-4039(96)02190-9

Isik, K., H.A. Kayali, N. Sahin, E. Ozturk and L. Tarhan, 2006. Antioxidant response of a novel Streptomyces sp. M3004 isolated from legume rhizosphere to $\mathrm{H} 2 \mathrm{O} 2$ and paraquat. Process Biochem., 42: 235-243.

Jayasri, M.A., A. Radha and T.L. Mathew, 2009. $\alpha-$ amylase and $\alpha$-glucosidase inhibitory activity of Costus pictus D. Don in the management of diabetes. J. Herbal Med. Toxicol., 3: 91-94.

Kim, K.J., M.A. Kim and J.H. Jung, 2008. Antitumor and antioxidant activity of protocatechualdehyde produced from Streptomyces lincolnensis M-20. Arch. Pharmacal. Res., 31: 1572-1577. PMID: 19099226

Kim, Y.M., Y.K. Jeong, M.H. Wang, W.Y. Lee and H.I. Rhee, 2005. Inhibitory effect of pine extract on $\alpha$ glucosidase activity and postprandial hyperglycemia. Nutrition, 21: 756-761. DOI: 10.1016/j.nut.2004.10.014

Komiyama, K., S. Funayama, Y. Anraku, A. Mita and Y. Takahashi et al., 1989. Isolation of isoflavonoids possessing antioxidant activity from the fermentation broth of Streptomyces sp. J. Antibiotics, 42: 1344 1349. PMID: 2793588

Kotowaroo, M.I., M.F. Mahomoodally, A. Gurib-Fakim and A.H. Subratty, 2006. Screening of traditional antidiabetic medicinal plants of Mauritius for possible alpha-amylase inhibitory effects in vitro. Phytother. Res., 20: 228-231. PMID: 16521114

Lazzarini, A., L. Cavaletti, G. Toppo and F. Marinelli, 2000. Rare genera of actinomycetes as potential producers of new antibiotics. Antonie van Leeuwenhoek, 78: 399-405. PMID: 11386363 
Magarvey, N.A., J.M. Keller, V. Bernan, M. Dworkin and Sherman, 2004. Isolation and characterization of novel marine-derived actinomycete taxa rich in bioactive metabolites. Applied Environ. Microbiol., 70: 7520-7529. PMID: 15574955

Mark, M. and W. Grell, 1997. Hypoglycaemic effects of the novel antidiabetic agent repaglinide in rats and dogs. Br. J. Pharmacol., 121: 1597-1604. PMID: 9283692

Mincer, T.J., P.R. Jensen, C.A. Kauffman and W. Fenical, 2002. Widespread and persistent populations of a major new marine actinomycete taxon in ocean sediments. Applied Environ. Microbiol., 68: 5005-11. PMID: 12324350

Nasik, S.R., 2003. Antioxidants and their role in biological functions: An overview. Ind. Drugs, 40: 501-515.

Okazaki, T. and Y. Okami, 1975. Actinomycetes tolerant to increased $\mathrm{NaCl}$ concentration and their metabolites. J. Ferment. Technol., 53: 833-840.

Remi, R.L. and L. Jean, 2004. Alpha-Glucosidase Inhibitors.

Saito, N. and M. Nei, 1987. The neighbour-joining method: A new method for reconstructing phylogenetic trees. Mol. Biol. Evol., 4: 406-425. PMID: 3447015

Shaw, J. E., R. A. Sicree, P. Z. Zimmet, 2010. Global estimates of the prevalence of diabetes for 2010 and 2030. Diab. Res. Clin. Practice, 87: 4-14. PMID: 19896746

Shetgiri, P.P. and P.M.D. Mello, 2003. Antioxidant activity of flavanoids-A comparitive study. Ind. Drugs, 40: 567-569.

Sosio, M., E. Bossi, A. Bianchi and S. Donadio, 2000. Multiple peptide synthetase gene clusters in actinomycetes. Mol. Gen. Genet., 264: 213-221. PMID: 11085259

Suthindhiran, K. and K. Kannabiran, 2009a. Cytotoxic and antimicrobial potential of Actinomycetes species Saccharopolysporra salina VITSDK4 isolated from the Bay of Bengal coast of India. Am. J. Infect. Dis., 5: 90-98.
Suthindhiran, K. and K. Kannabiran, 2009b. Hemolytic activity of Streptomyces VITSTDK1 sp. nov. isolated from marine soil in southern India. J. Med. Mycol., 19: 77-86.

Suthindhiran, K. and K. Krishnan, 2010. Diversity and exploration of bioactive marine actinomycetes in the Bay of Bengal of the Puducherry coast of India. Ind. J. Microbiol., 50: 76-82. DOI: 10.1007/s12088-0100048-3

Suthindhiran, K., V.S. Babu, V.P.I. Ahmed, A.S.S. Hameed and K. Kannabiran, 2011. Anti-fish nodaviral activity of furan-2-yl acetate extracted from marine Streptomyces spp. Natural Product. Res., 25: 834-843. DOI: 10.1080/14786419.2010.530599

Suthindhiran, K.R., M.A. Jayasri and K. Kannabiran, 2009. $\alpha$-glucosidase and $\alpha$-amylase inhibitory activity of Micromonospora sp. VITSDK3 (EU551238). Int. J. Integ. Biol., 6: 115-120.

Terashita, T., M. Kono and S. Murao, 1980. Promoting effect of S-PI on fruiting of Lentinus edodes. Trans. Mycol. Soc. Jpn., 21: 137-140.

Toeller, M., 1994. Alpha-Glucosidase inhibitors in diabetes: Efficacy in NIDDM subjects. Eur. J. Clin. Invest, 24: 31-35. PMID: 8001625

Umezawa, H., 1972. Enzyme Inhibitors of Microbial Origin. 1st Edn., University Park Press, Baltimore, ISBN-10: 083910734X, pp: 114.

Yang, B., J. Wang, M. Zhao, Y. Liu and W. Wang et al., 2006. Identification of polysaccharides from pericarp tissues of litchi (Litchi chinensis Sonn.) fruit in relation to their antioxidant activities. Carbohydr. Res., 341: 634-638. PMID: 16442509

Yu, B.P., 1994. Cellular defenses against damage from reactive oxygen species. Physiol. Rev., 76: 139-162. PMID: 8295932 